\title{
Strategi Media Relations PT Bio Farma dalam Menjaga Reputasi Perusahaan
}

\author{
Ariz Rizaldi ${ }^{*}$, Ujang Saefullah $1^{1}$, Lida Imelda Cholidah $2^{2}$ \\ 1 Jurusan Ilmu Komunikasi Humas, Fakultas Dakwah dan Komunikasi, UIN Sunan Gunung \\ Djati, Bandung \\ ${ }^{2} J u r u s a n$ Komisi dan Penyiaran Islam, Fakultas Dakwah dan Komunikasi, UIN Sunan Gunung \\ Djati, Bandung \\ *Email : Ariz.rizaldi1998@gmail.com
}

\begin{abstract}
ABSTRAK
Penelitian ini bertujuan untuk mengetahui bagaimana proses strategi Media Relations PT Bio Farma (Persero) melalui Media Gathering dalam menjaga reputasi perusahaan. Secara lebih rinci tujuan penelitian ini untuk mengetahui tahapan proses strategi tersebut, mulai dari tahap mencari data sampai evaluasi. Penelitian ini didasarkan pada konsep Four Step Public Relations kemudian dianalogikan pada proses strategi Media Relations yang implementasinya identik dengan aktivitas strategi yang di dalamnya terdiri dari pencarian data, perencanaan dan pemrograman, pengambilan tindakan, dan evaluasi. Metode yang digunakan merupakan metode deskriptif dan teknik pengumpulan datanya melalui observasi dan wawancara secara mendalam. Hasil penelitian menunjukan bahwa kegiatan Media Gathering yang dilakukan oleh PT Bio Farma (Persero) terdiri dari beberapa kegiatan, bersifat formal dan informal. Kegiatan formal berisi pemberian informasi dan materi mengenai perusahaan tentang hal yang akan dilakukan oleh perusahaan sehingga perlu dipublikasi, kegiatan informal berisi kegiatan "Fun" seperti outbound hal ini bertujuan untuk pendakatan personal antara perusahaan dengan media.
\end{abstract}

Kata Kunci: Media Relations, Media Gathering, Reputasi

\section{ABSTRACT}

This study aims to determine how the strategic process of PT Bio Farma (Persero) Media Relations through Media Gathering in maintaining the company's reputation. In more detail, the purpose of this study is to determine the stages of the strategy process, from the data search stage to evaluation. This research is based on the concept of Four Step Public Relations and then analogous to the process of Media Relations strategy whose implementation is identical to strategic activities consisting of data search, planning and programming, taking action, and evaluation. The method used is descriptive method and data collection techniques through observation and in-depth interviews. The results showed that the Media Gathering activities conducted by PT Bio Farma (Persero) consisted of several activities both formal and informal. 
A. Rizaldi, U. Saefullah, L. I. Cholidah

Formal activities include providing information and material about the company about what the company will do so that it needs to be published, informal activities contain "Fun" activities such as outbound activities aimed at personal approaches between the company and the media.

Keywords: Media Relations, Media Gathering, Reputation

\section{PENDAHULUAN}

Media Relations merupakan bagian dari kegiatan hubungan eksternal yang dilakukan oleh seorang Public Relations di dalam sebuah perusahaan atau organisasi, yang berkaitan dengan menjalin hubungan baik dengan media guna menjaga dan meningkatkan reputasi perusahaan atau organisasi itu sendiri. Media Relations juga berfungsi sebagai sebuah sarana bakal penyebaran suatu informasi yang dimiliki perusahaan kepada publik mengenai suatu peristiwa, misalnya kegiatan sebuah perusahaan yang harus disebarkan melalui publikasi, yang diharapkan pesan yang dimuat oleh media merupakan pesan yang baik dan sampai kepada publik. Media Relations juga berkaitan dengan kegiatan perusahaan dalam menanggapi suatu isu atau peristiwa yang sedang dialami kepada media, salah contoh kegiatannya yaitu konferensi pers, media briefing dan kegiatan yang biasanya dilakukan dengan rutin yaitu Media Gathering.

Praktiknya, Media Relations bisa berupa kegiatan-kegiatan yang diadakan oleh organisasi atau perusahaan guna meningkatkan atau menjaga hubungan baik dengan media, seperti Media Gathering. Menjaga hubungan baik dengan media sangat penting dan harus dilakukan oleh praktisi PR, karena dari medialah reputasi perusahaan terbangun.

Media Gathering sendiri merupakan kegiatan yang biasanya rutin dilakukan oleh perusahaan di mana kegiatan diadakan oleh perusahaan dengan mengundang media. Media Gathering biasanya kegiatan yang bertujuan untuk meningkatkan hubungan perusahaan dengan media, kegiatan ini juga biasanya menjadi laporan atau report perusahaan tentang hal-hal yang akan dan telah dilakukan oleh perusahaan, hal ini tentunya bagus untuk penyediaan informasi kepada media. Media Gathering juga mengadakan kegiatan-kegiatan yang bertujuan untuk meningkatkan hubungan personal dengan media seperti outbound dan bermain games yang diadakan oleh perusahaan.

Nasir, Yusran (2018) dalam jurnalnya yang berjudul Aktivitas Media Relations Humas Pemerintah Kota Sabang dalam Membangun Hubungan Dengan Media Massa, volume 3, nomor 2, halaman 385-386 menjelaskan tentang aktivitas Media Relations yang dilakukan Humas Pemerintah Kota sabang serta tantangan dan kendala yang dihadapi oleh Humas dengan menjalin relasi dengan media. Penelitian ini menemukan kegiatan Media Relations yang dilakukan oleh praktisi Public Relations di antaranya konferensi pers, coffee morning, dan memberi kemudahan akses informasi untuk media. Perusahaan yang melakukan 
relasi dengan media dengan melakukan beberapa kegiatan di atas harus juga melakukan beberapa kegiatan infromal lainnya supaya hubungan personal dengan media terjalin dengan sangat baik guna mencapai tujuan yang telah disepakati bersama.

Herlina, Nela, Rani dan Eli (2019) mengatakan dalam jurnalnya yang berjudul Manfaat Internet Corporate sebagai Media Relations Hotel Java Retro \& Suites, volume 2, nomor 1, halaman 32-39 bahwa Media Relations merupakan kegiatan kerja sama antara public relations dengan media. Penelitian ini menjelaskan bahwa public relations dapat memanfaatkan internet corporate atau Cyber Public Relations yang dimiliki oleh perusahaan untuk menjalin hubungan dengan media, karena dengan dikelolanya atau dimanfaatkannnya Cyber Public Relations yang dimiliki oleh perusahaan nantinya media akan sangat mudah untuk mengakses dan mendapatkan informasi yang tepat dan cepat karena bersumber langsung dari public relations melalui Cyber Public Relations yang dimiliki oleh perusahaan.

Vidiarti, Putri (2018) dalam jurnalnya yang berjudul Peran Media Relations dalam Mengimplementasikan Program Kedinasan melalui Pendekatan Informal, volume 3, nomor 2, halaman 20-39 mengatakan bahwa peran Media Relations dapat dilakukan dengan cara informal seperti halnya yang dilakukan oleh PEMDA Purwakarta. PEMDA Purwakarta menurut Putri mengambil tiga tindakan yaitu yang pertama bagian perencanaan dengan beberapa cara seperti memetakan program dinas, membentuk hubungan personal, mengelola relasi, memberikan layanan kepada media, memberikan fasilitas terhadap media, dan yang lainnya. Kedua, implementasi dilakukan dengan cara komunikasi persuasif, koordinasi dengan pihak terkait, pengelolaan konten, dan mengacu pada peraturan yang telah disepakati. Ketiga, terakhir merupakan tahap evaluasi yang dilakukan dengan cara briefing internal, meminta klarifikasi terhadap kesalahan media, bekerjasama membuat tim monitoring, mengupdate database media. Proses Media Relations guna menunjang keberhasilan dalam pencapaian publikasi melalui pendekatan informal dirasa efektif karena sesuai dengan apa yang diharapkan oleh PEMDA Purwakarta.

Perbedaan penelitian peneliti dengan penelitian terdahulu terdapat pada objek dan lokasi penelitian, objek penelitian peneliti yaitu Strategi Media Gabtering yang dilakukan oleh bagian Corporate Communication sebagai bentuk dari Media Relations yang dilakukan oleh PT Bio Farma (Persero) yang tentunya setiap perusahaan memiliki strategi tersendiri sesuai dengan fokus bisnis dari perusahaannya, juga pada teori atau konsep yang digunakan, peneliti menggunakan konsep Four Step Public Relations Oleh Cutlip, Center, dan Broom dalam bukunya Effective Public Relations yang dianalogikan pada strategi Media Relations dengan bentuk kegiatan Media Gathering. 
Lokasi penelitian yaitu PT Bio Farma (Persero) merupakan BUMN produsen Vaksin dan Antisera yang saat ini berkembang menjadi perusahaan Life Science yang didirikan pada 6 Agustus 1890, selama 128 tahun berdiri Bio Farma telah berkontribusi untuk meningkatkan kualitas hidup bangsa, baik di Indonesia maupun mancanegara. Berdasarkan data pra penelitian, PT Bio Farma (Persero) melakukan kegiatan yang berkaitan dengan Media Relations yaitu Media Gathering yang dilakukan setiap satu tahun sekali, terakhir dilakukan pada 17 September 2019. Hal itu juga terlihat dari kemudahan PT Bio Farma (Persero) pada saat memuat berita melalui media. Berita-berita yang dimuat di media yang berkaitan dengan Bio Farma, di mana berita yang keluar selalu tentang isu yang positif yang tentunya baik untuk perusahaan. PT Bio Farma (Persero) juga pernah mendapat penghargaan Keterbukaan Informasi Badan Publik pada 12 desember 2013 di Jakarta. Penghargaan bertujuan mengetahui tingkat pelaksaaan UndangUndang No 14/2008 tentang KIP dari badan publik dalam menjalankan kewajiban dan memberikan akses informasi publik kepada masyarakat. Berita ini dimuat oleh Kominfo.co.id dan BioFarma.co.id.

Penelitian ini bertujuan untuk mengetahui bagaimana PT Bio Farma (Persero) dalam mengelola kegiatan Media Gathering secara mendalam. Hal yang dijelaskan pada paragraf di atas jadi dasar keinginan peneliti untuk menggali dan menjelaskan Strategi Media Relations PT Bio Farma (Persero) dalam menjaga reputasi melalui Media Gathering secara mendalam yang dilakukan oleh PT Bio Farma (Persero) guna mempererat hubungan yang baik dengan media sehingga dapat meningkatkan dan menjaga reputasi perusahaan.

\section{LANDASAN TEORITIS}

Landasan teoritis pada penelitian ini menggunakan konsep Four Step Public Relations yang dikemukakan oleh Cutlip, Center dan Broom (2009: 321) dalam buku Effective Public Relations kemudian dianalogikan pada proses strategi Media Relations yang implementasinya identik dengan aktivitas strategi. roses Public Relations sangat mengacu pada pendekatan manajerial, bahwa Public Relations merupakan kegiatan yang di mana prosesnya melalui empat tahap.

Empat tahap yang dimaksud di atas merupakan:

Pertama, Fact Finding, merupakan pengumpulan data dari analisis tentang sesuatu yang akan dikerjakan. Tahap ini juga sebagai dasar acuan untuk langkah selanjutnya.

Kedua, Planning and Programing, Tahap ini merupakan tahap penyusunan rencana dan dijadikan program dari data yang ditemukan pada tahap pertama.

Ketiga, Taking Action, Tahap ketiga merupakan melakukan tindakan atas rencana program yang sudah ditetapkan guna mencapai tujuan setelah mengumpulkan data dan merencanakan program.

Keempat, Evaluating, Tahap terakhir merupakan penilaian program dari 
setiap tahap yang sudah dilakukan.

\section{HASIL DAN PEMBAHASAN}

Interpretasi dari kegiatan Media Gathering yang dilakukan oleh PT Bio Farma (Persero) melalui Bagian Corporate Communication sebagai strategi Media Relations dalam menjaga reputasi dilakukan melalui beberapa tahap. Kegiatan-kegiatan yang dilakukan juga tentunya bertujuan untuk menjalin hubungan yang baik antara perusahaan dengan publiknya. Sejalan dengan pernyataan dari Cutlip, Center, dan Broom (dalam Ardianto, 2011: 9) Public Relations merupakan fungsi manajemen yang secara khusus mendukung terciptanya saling pengertian dalam komunikasi, pemahaman, penerimaan, dan kerja sama antara organisasi dengan publiknya.. PT Bio Farma (Persero) melakukan hal yang benar ketika melakukan salah satu jenis hubungan eksternal yaitu Media Relations dengan jenis kegiatan rutin yang diselenggarakan oleh perusahaan satu tahun sekali yaitu Media Gathering.

Hasil dari penelitian ini menemukan cara PT Bio Farma (Persero) dalam mengelola Strategi Media Relations dengan bentuk kegiatan Media Gathering agar reputasi perusahaan tetap terjaga, dengan melakukan beberapa tahap.

\section{Strategi Bagian Corporate Communication dalam Mencari Data atau Menganilisis Situasi}

Strategi merupakan sesuatu yang penting untuk perusahaan guna mencapai tujuan dengan cara yang efektif, perusahaan harus bisa menghadapi masalah baik dari internal perusahaan maupun eksternal. Strategi merupakan rencana yang terkonsep, strategi dalam dunia usaha sangatlah dibutuhkan untuk mencapai tujuan yang ditetapkan oleh perusahaan. Menempatkan Media Relations sebagai strategi perusahaan dalam menjaga reputasi perusahaan merupakan hal yang sangat tepat, Media Relations sendiri bertujuan untuk menjalin hubungan yang baik dengan media. Seusai dengan yang Iriantara, (2011:27) katakan yaitu Membangun hubungan yang baik dengan media massa menjadi sangat penting, dengan hubungan baik tersebut maka media massa dapat dijadikan mitra untuk memaksimalkan pengkomunikasian informasi, citra atau gagasan yang berasal dari organisasi kepada publik-publiknya. Oleh karena itu, strategi yang dibuat harus sangat terencana dengan matang.

Berdasarkan hasil wawancara dengan Bapak Iwan Setiawan sebagai Kepala Bagian Corporate Communications, strategi yang digunakan pada tahap awal yaitu mencari data atau menganalisis situasi. Situasi yang mengharuskan perusahaan menyelenggarakan kegiata Media Gathering berangkat dari kebutuhan perusahaan untuk menaikan berita tentang perusahaanya, PT Bio Farma sendiri melakukan kegiatan Media Gathering untuk kebutuhan penyampaian informasi tentang proses bisnis bioteknologi yang merupakan core 
bisnis Bio Farma. Hal ini untuk memudahkan media dalam memberikan informasi dan edukasi kepada masayarakat, serta untuk meminimalisir kesalahan dalam pemberitaan tentang dunia kesehatan. Selain hal di atas, data yang diambil untuk kegiatan ini merupakan data dari internal dan eksternal perusahaan, data internal merupakan data dari perusahaan yaitu hal-hal yang akan dilakukan oleh perusahaan selama setahun ke depan. Sedangkan data dari eksternal yaitu dari media sendiri salah satunya merupakan data yang diambil dari kuesioner yang biasanya dibagikan pada kegiatan Media Gathering sebelumnya setelah acara selesai, dengan begitu perusahaan dapat mengetahui pendapat media dalam kegiatan tersebut. Media yang diundang dalam kegiatan tersebut merupakan media-media yang bergelut pada bidang kesehatan, ekonomi, dan media mainstream. Media-media tersebut nantinya diharapkan akan mempublikasi berita tentang perusahaan, baik itu dari segi kesehatan, ekonomi, dan lain-lain. Data-data yang didapat nantinya menentukan program dan kegiatan yang akan dilakukan pada kegiatan Media Gathering. Dengan adanya data tersebut tentunya sangat berpengaruh pada tahap selanjutnya, tahapan awal juga yang akan menentukan tema kegiatan yang akan digunakan dan menjadi gambaran untuk hal yang perlu disampaikan pada saat kegiatan berlangsung.

\section{Strategi Bagian Corporate Communication dalam Menyusun Perencanaan Program}

Pada tahap ini, Bagian Corporate Communication menyusun rencana kegiatan dari data-data yang terkumpul pada tahap sebelumnya. Rencana yang disusun tentunya harus sangat matang agar menghindari gangguan pada saat kegiatan berlangsung. Pada tahap ini juga perusahaan membuat Term of Reference (TOR) atau Kerangka Acuan Kerja (KAK) yang memuat batasan mengenai gambaran tujuan, ruang lingkup, dan anggaran sebagai referensi dalam pelaksanaan Media Gathering. Dari data-data yang sudah terkumpul tentunya tidak terlalu sulit dalam menyusun rencana kegiatan, perusahaan sudah mengetahui apa saja infromasi yang harus disampaikan kepada media sehingga nanti media menyebarkan kembali informasi tersebut kepada publik. Pada praktiknya kegiatan Media Gathering dilakukan dengan dua bentuk, yaitu formal dan infromal. Kegiatan formal berisi pemberian informasi dan materi dari perusahaan kepada media tentang apa saja yang akan dilakukan oleh perusahaan sedangkan informal merupakan kegiatan-kegiatan "fun" agar pelaku media merasa nyaman berada dalam kegiatan tersebut, biasanya kegiatan informal berisi kegiatan outbound atau doorprize dan kegiatan-kegiatan lainnya. Kegiatan informal biasanya sedikit lebih banyak dari kegiatan formal, itu bertujuan untuk membuat pihak dari media merasa nyaman dengan perusahaan karena "goals" yang hendak dicapai merupakan terjalinnya hubungan yang baik antara perusahaan dengan media. Media mendapatkan informasi dari perusahaan untuk dijadikan bahan berita dan perusahaan dapat mempublikasikan berita mereka, 
hal itu tentunya saling menguntungkan kedua belah pihak. Sesuai dengan yang dikatakan Frank Jefkins (2003: 117) dalam prinsip Media Relations yaitu seorang humas harus dapat memahami dan melayani media agar dapat menciptakan suatu hubungan timbal balik yang saling menguntungkan antara media dengan lembaga terkait.

Berdasarkan hasil wawancara dengan Ibu Yuni Miyansari sebagai Staff di Bagian Corporate Communication, pada tahap ini perusahaan biasanya menyusun materi yang akan disampaikan pada saat seminar nanti. Karena tidak semua media yang diundang memiliki latar belakang kesehatan, biasanya perusahaan mengadakan kegiatan yang bernama "School of vaksin for jurnalis", kegiatan itu berisi memberi tahu istilah-istilah seputar kesehatan atau vaksin yang merupakan produk dari Bio Farma, sehingga ketika wartawan menuliskan berita mereka memiliki "feep' karena paham dengan istilah-istilah yang diberikan seperti pengertian vaksin atau imunisasi dan apa pentingnya kedua hal tersebut. Pemilihan Narasumber juga ditentukan pada tahap ini, baik itu narasumber dari internal perusahaan ataupun eksternal perusahaan. Narasumber juga berbeda pada tiap sesi, ketika pemberian informasi tentang kesehatan maka yang menjadi narasumber harus dari background kesehatan, begitupun dengan ekonomi, yang tentunya narasumber yang dipilih merupakan orang yang ahli "experp" pada bidangnya masing-masing. Hal itu tentunya sangat bagus agar materi atau informasi yang disampaikan tidak salah karena disampaikan langsung oleh ahlinya. Selain tema kegiatan, tema pakaian juga ditentukan pada tahap ini, pakaian yang dipakai tentunya menyesuaikan dengan tema atau tempat yang akan dipakai ketika kegiatan berlangsung, pada Media Gathering Tahun 2019 PT Bio Farma memberi merchendise berupa jaket dengan logo Bio Farma karena kegiatan berlangsung di tempat yang cukup dingin yaitu di daerah lembang. Jaket dengan logo tersebut tentunya bagus untuk branding perusahaan agar dikenal oleh publik eksternal.

\section{Strategi Bagian Corporate Communication dalam Mengambil Tindakan atau Taking Action}

Tahap ini merupakan pengambilan tindakan atau melaksakan rangkaian acara secara keseluruhan dengan semua program yang sudah direncanakan pada tahapan sebelumnya, di antaranya yaitu program edukasi atau pemberian informasi dan materi mengenai apa saja yang akan dilakukan oleh PT Bio Farma (Persero) selama setahun ke depan, pemberian informasi dan materi bertujuan agar wartawan sebagai pelaku media memahami perusahaan dan mendapatkan materi atau informasi untuk bahan berita. Informasi dan materi yang disampaikan tentunya diharapkan akan disebarkan lagi kepada masyarakat melalui berita yang ditulis oleh wartawan tersebut, berita-berita yang dipublikasi oleh media tentunya bagus untuk reputasi perusahaan. Sejalan dengan yang 
disampaikan oleh Ruslan (2007:172) mengatakan Media Relations merupakan hubungan yang baik dengan pihak media massa, hubungan baik tersebut dibangun melalui suatu kejujuran, serta mau membantu untuk pelayanan pemberian sumber berita atau informasi yang diperlukan dalam suasana saling menghormati, dan adanya keterusterangan.

Berdasarkan hasil wawancara dengan Bapak Iwan Setiawan dan Bapak Edwin Garna Pringadi, kegiatan yang dilakukan tentunya sesuai dengan susunan rencana yang telah disiapkan sebelumnya. Pada hari pertama dilakukanya Media Gathering biasanya diadakan workshop bagi media dengan mendatangkan narasumber baik itu dari internal ataupun eksternal perusahaan, pada tahap ini juga pihak media diperbolehkan untuk bertanya terkait informasi apa saja yang mereka butuhkan terkait perusahaan. Selain itu, pihak media dipersilahkan melakukan wawancara kepada direksi, narasumber, dan sekretaris perusahaan.

Pada hari kedua biasanya perusahaan dan media melakukan kegiatan bersifat "fun" berupa outbound yang diisi dengan permainan-permainan yang seru, kegiatan ini bertujuan agar terciptanya hubungan antar personal antara perusahaan dengan pelaku media sehingga mereka merasa nyaman dan merasa dianggap oleh perusahaan, sehingga nantinya pihak media mau untuk memuat berita-berita yang berkaitan dengan perusahaan tanpa harus dipaksa.

\section{Strategi Bagian Corporate Communication dalam Proses Evaluasi Kegiatan Media Gathering}

Tahap terakhir merupakan tahap evaluasi, evaluasi kegiatan Media Gathering yang dilakukan oleh PT Bio Farma (Persero) sesuai dengan konsep four step public relations yaitu melakukan penilaian atas hasil yang didapat dari seluruh tahapan, mengenai berhasil atau tidaknya program tersebut dilaksanakan.

Pelaksanaan tahap terakhir ini yaitu evaluating the program, Bagian Corporate Communication PT Bio Farma (Persero) mengevaluasi seluruh tahapan. Pada tahap ini Bagian Corporate Communication membagikan kuesioner kepada semua peserta kegiatan, kuesioner tersebut berisi tentang penilaian dan pendapat mengenai hal-hal yang berkaitan dengan kegiatan Media Gathering seperti materi yang disampaikan, makanan yang disajikan, konsep atau tema yang dipakai. Pada kuesioner juga meminta pendapat dari pihak media untuk kegiatan Media Gathering selanjutnya. Dari kuesioner tersebut perusahaan memperoleh saran sekaligus data yang nantinya akan dipakai dalam kegiatan tahun depan.

Evaluasi yang dilakukan ini juga untuk menilai berhasil atau tidaknya kegiatan Media Gathering yang dilakukan oleh Bagian Corporate Communication PT Bio Farma (Persero) dalam menjaga reputasi perusahaan. Berdasarkan hasil wawancara dengan Bapak Iwan Setiawan dan Bapak Edwin Garna Pringadi, kegiatan Media Gathering dinilai cukup memiliki peran penting dalam menjaga reputasi. Kegiatan tersebut dinilai dapat menjaga dan meningkatkan hubungan baik antara perusahaan dengan publiknya. Isu-isu yang beredar di masyarakat 
tidak langsung dijadikan berita oleh media, tetapi media langsung mengkonfirmasi kebenaran isu tersebut kepada perusahaan. Berita-berita yang dimuatpun tentu tentang isu yang positif dan menguntungkan perusahaan. Sejalan dengan Wardhani (2008: 13) mengakatan program Media Relations dijalankan oleh seorang Public Relations untuk menjaga hubungan baik dengan media, apabila organisasi sudah dikenal baik oleh media, maka diharapkan bila ada undangan liputan, mereka akan datang dan mempublikasikan informasi organisasi dengan sukarela, bila terjadi krisis maka mereka juga mampu menghasilkan publikasi yang berimbang, tidak semata menyudutkan organisasi dan berakibat pada pembentukan image negatif.

Hal tersebut tentunya sangat penting, mengingat pada hari ini informasi bisa diakses dari mana saja dan tidak dapat terkontrol. Kegiatan ini berfungsi untuk meminimalisir isu-isu negatif tentang perusahaan sehingga reputasi dari perusahaan tetap terjaga. Media Gathering juga diharapkan bisa membuat pihak media mau secara sukarela mempublikasikan Release yang dibuat oleh perusahaan tanpa adanya paksaan, dikarenakan media dan perusaahan sudah saling mengenal dengan baik dan saling menghormati.

\section{PENUTUP}

Berdasarkan hasil analisis dan pembahasan yang ditemukan di lapangan mengenai Strategi Media Relations PT Bio Farma (Persero) dalam Menjaga Reputasi Perusahaan dapat disimpulkan sebagai berikut:

Pertama, pelaksanaan Strategi Bagian Corporate Communication PT Bio Farma (Persero) dalam bentuk Media Relations yaitu dengan kegiatan Media Gathering pada tahap pertama merupakan analisis situasi dan mencari data. Analisis situasi yang dilakukan oleh Bagian Corporate Communication yaitu melihat apa saja yang akan dilakukan oleh perusahaan setahun ke depan sehingga informasi dirasa perlu diberikan kepada media agar dipublikasi. Data yang diambil oleh Bagian Corporate Communication merupakan data dari internal dan eksternal perusahaan, data internal sendiri merupakan data-data tentang sustainable bisnis perusahaan yang akan dilakukan, sedangkan data dari eksternal merupakan datadata wartawan yang perlu diundang dan data dari kuesioner yang dibagikan pada kegiatan Media Gathering sebelumnya.

Kedua, pelaksanaan Strategi Bagian Corporate Communication PT Bio Farma (Persero) dalam bentuk Media Relations yaitu dengan kegiatan Media Gathering pada tahap kedua yaitu menyusun perencanaan program. Setelah data-data terkumpul maka Bagian Corporate Communication menyusun rencana untuk program yang nanti akan dilakukan pada saat kegiatan berlangsung. Pada tahap ini biasanya Bagian Corporate Communication membuat tema kegiatan dan Term of Reference (TOR) atau Kerangka Acuan Kerja (KAK) yang berisi tentang tujuan, 
ruang lingkup, dan anggaran sebagai referensi dalam pelaksanaan kegiatan. Bagian Corporate Communication juga melakukan survei ke beberapa lokasi sesuai dengan rencana agar kegiatan ini dilakukan di tempat yang tepat.

Ketiga, pelaksanaan Strategi Bagian Corporate Communication PT Bio Farma (Persero) dalam bentuk Media Relations yaitu dengan kegiatan Media Gathering pada tahap yang ketiga yaitu pengambilan tindakan atau taking action. Pada tahap ini Bagian Corporate Communication melakukan pengambilan tindakan pada saat kegiatan berlangsung sesuai dengan rencana yang disusun pada tahap sebelumnya. Kegiatan yang dilakukan biasanya dilakukan dengan dua bentuk, yaitu formal dan informal. Kegiatan formal berisi penyampaian materi atau informasi melalui seminar dengan narasumber yang ahli pada bidang materi yang disampaikan kepada media. Informal merupakan kegiatan-kegiatan yang bersifat "fun" berisi games, outbound dan lain-lain agar media merasa nyaman berada dalam kegiatan tersebut dan terjalinnya hubungan antar personal antara perusahaan dengan media.

Keempat, pelaksanaan Strategi Bagian Corporate Communication PT Bio Farma (Persero) dalam bentuk Media Relations yaitu dengan kegiatan Media Gathering pada tahap terakhir merupakan evaluasi program. Bagian Corporate Communication dalam melakukan evaluasi dengan cara menyebarkan kuesioner setelah acara selesai, penyebaran kuesioner tersebut bertujuan untuk mengetahui pendapat dari kegiatan Media Gathering yang telah selesai dilakukan mulai dari makanan, konsep acara dan lain-lain. Kuesioner juga berisi untuk meminta usulan dari pihak media untuk kegiatan Media Gathering berikutnya. Hasil dari kegiatan tersebut dalam menjaga reputasi dapat dilihat dari tidak adanya berita buruk tentang perusahaan karena wartawan selalu mengkonfirmasi dahulu terhadap isu-isu yang sedang beredar kepada perusahaan sebelum membuat berita. Evaluasi bertujuan untuk menilai berhasil atau tidaknya program tersebut untuk mencapai tujuan yang dibuat pada tahap awal.

\section{DAFTAR PUSTAKA}

Ardianto Elvinaro. 2011. Handbook of Public Relations (Pengantar Komprehensif). Bandung : Simbiosa Rekatama Media.

Jefkins, Frank. 2003. Public Relations Edisi kelima, Jakarta: PT Gelora Aksara Pratama

Herlina, Nela, Rani dan Eli. 2019. Manfaat Internet Corporate sebagai Media Relations Hotel Java Retro \& Suites. 02 (1), 32-39.

Iriantara, Yosal. (2011). Hubungan Media. Konsep, Pendekatan dan Praktik. Bandung: PT. Remaja Rosdakarya.

Nasir, Yusran. 2018. Aktivitas Media Relations Humas Pemerintah Kota Sabang dalam Membangun Hubungan Dengan Media Massa. 03 (2), 385-386.

Vidiarti, Putri. (2018). Peran Media Relations dalam Mempublikasikan Program 
Kedinasan melalui Pendekatan Informal. Dalam Jurnal Komnikasi. 03 (2), 20-39.

Ruslan, Rosady. 2007. Manajemen Public Realtions \& Media Komunikasi: Konsepsi dan Aplikasi. Jakarta: PT Raja Grafindo Persada. 
A. Rizaldi, U. Saefullah, L. I. Cholidah 